\title{
Pengaruh Ekstrak Jintan Hitam terhadap MDA dan Sel Spermatogonium Tikus yang Dipapar Asap Rokok Kretek Subakut
}

\section{The Effect of Black Seed on MDA and Spermatogonium Cell of Rat Exposed with Sub Acute Cigaratte Smoke}

\author{
Happy Kurnia $P^{1}$, Nur Permatasari $i^{2}$, Subandi \\ ${ }^{1}$ Program Studi Pendidikan Dokter Universitas Brawijaya Malang \\ ${ }^{2}$ Laboratorium Farmakologi Fakultas Kedokteran Universitas Brawijaya Malang \\ ${ }^{3}$ Laboratorium Anatomi-Histologi Fakultas Kedokteran Universitas Brawijaya Malang
}

\begin{abstract}
ABSTRAK
Radikal bebas dalam asap rokok diketahui dapat menyebabkan gangguan infertilitas. Aktivitas radikal bebas dapat dihambat oleh antioksidan seperti yang terkandung dalam jintan hitam (thymoquinone, nigellone, carvacrol, $t$-anethole dan 4-terpineol). Tujuan penelitian ini adalah untuk mengetahui pengaruh ekstrak jintan hitam terhadap kadar Malon Di Aldehid (MDA) testis dan jumlah sel spermatogonium testis tikus yang dipapar asap rokok kretek selama 21 hari (subakut). Penelitian eksperimental ini menggunakan 20 ekor tikus (Rattus norvegicus) strain Wistar jantan yang dibagi menjadi 5 kelompok, terdiri dari kelompok kontrol negatif, kelompok kontrol positif, kelompok perlakuan 1, 2, dan 3 (masing-masing dipapar asap rokok kretek dan diberi ekstrak jintan hitam dosis 0,6; 1,2; 2,4 g/kgBB/hari secara berurutan). Kadar MDA testis diukur menggunakan metode Thio Barbituric Acid test (TBA Test). Testis tikus dijadikan preparat histopatologi menggunakan pengecatan Haematoxcylin Eosin (HE), untuk dihitung jumlah sel spermatogonium yang melekat pada membrana basalis. Dapat disimpulkan bahwa jintan hitam mempunyai efek antioksidan, yaitu dapat mencegah penurunan jumlah sel spermatogonium pada tubulus seminiferus testis tikus strain Wistar melalui hambatannya pada pembentukan peroksidasi lipid (MDA) akibat paparan asap rokok kretek subakut.
\end{abstract}

Kata Kunci: Asap rokok kretek, jintan hitam, MDA testis, sel spermatogonium

\begin{abstract}
Free radicals in cigarette smoke was known could promote infertility. Free radicals activity can be inhibited by antioxidant in black seed (thymoquinone, nigellone, carvacrol, t-anethole, and 4-terpineol). The aim of this study was to assess the effect of black seed extract on MDA concentration in testis and spermatogonium cell number in subacute nonfilter-tipped cigarette smoke exposed rats. The MDA concentration in testis and spermatogonium cell number was the indicator of testicular damage caused by free radicals activity. This experimental study using 20 male Wistar strain rats (Rattus norvegicus) which randomly divided into five groups, as follows: the control negative group, the control positive group, the first, the second, and the third treatment groups (exposed to nonfilter-tipped cigarette smoke and treated with black seed extract 0,$6 ; 1,2 ; 2,4 \mathrm{~g} / \mathrm{kgBB} /$ day subsequently). The MDA concentration in testis was measured by Thio Barbituric Acid test methode. Testis made into histopathologycal preparation using Haematoxcylin Eosin (HE) staining, for counting the spermatogonium cell number. It could be concluded that black seed have antioxidant activity to prevent decreasing spermatogonium cell by inhibit lipid peroxida caused by subacute nonfilter-tipped cigarette smoke exposure.
\end{abstract}

Keywords: Black seed extract, cigarette smoke, MDA testis, spermatogonium cell

Jurnal Kedokteran Brawijaya, Vol. 26, No. 3, Februari 2011; Korespondensi: Happy Kurnia P. Program Studi Pendidikan Dokter Fakultas Kedokteran Universitas Brawijaya Malang, Jl. Veteran Malang Tel. (0341)569117Email:drhappypermatasari@gmail.com 


\section{PENDAHULUAN}

Asap rokok mengandung kurang lebih 4000 bahan beracun seperti alkaloids, nitrosamines, dan molekulmolekul inorganik. Asap rokok juga berkaitan dengan infertilitas pria, beberapa penelitian melaporkan adanya efek asap rokok terhadap spermatogenesis, kualitas sperma, maupun hormon yang mempengaruhinya yaitu testosteron. Penelitian oleh Raipurkar, melaporkan bahwa paparan asap rokok kronik menyebabkan apoptosis pada sel spermatogenik tikus (1). Anita, juga melaporkan bahwa terdapat penurunan kadar testosteron, berat testis, jumlah sel-sel spermatogenik, dan adanya perubahan sebaran stadia epitel seminiferus setelah dipapar asap rokok dalam beberapa stadia sel spermatogenik (2).

Radikal bebas yang terkandung dalam asap rokok merupakan molekul biologik yang mempunyai satu atau lebih elektron yang tidak berpasangan pada orbit terluarnya, sehingga bersifat tidak stabil dan reaktif. Salah satu substansi yang paling rentan terhadap radikal bebas adalah PUFA (Poly Unsaturated Fatty Acid) atau asam lemak tak jenuh. Ikatan antara radikal bebas dan PUFA akan menyebabkan peroksidasi lemak.

Aktivitas radikal bebas dapat dihambat oleh antioksidan. Antioksidan adalah substansi yang diperlukan tubuh untuk menetralisir radikal bebas dan mencegah kerusakan yang ditimbulkan oleh radikal bebas terhadap sel normal, protein, dan lemak. Bahan alam yang mengandung antioksidan yang kuat salah satunya adalah jintan hitam (Nigella sativa). Jintan hitam mengandung beberapa antioksidan seperti thymoquinone, nigellone, carvacrol, t-anethol, dan 4-terpineol (3-5). Antioksidan yang terkandung didalamnya mempunyai efek antioksidan yang kuat dan distribusinya luas ke jaringan termasuk jaringan testis serta aman penggunaannya (2). Dengan alasan tersebut maka perlu dilakukan penelitian mengenai efek proteksi dari jintan hitam terhadap kualitas dan kuantitas sel spermatogenik pada keadaan akibat paparan asap rokok. Dari hasil penelitian ini diharapkan jintan hitam nantinya dapat digunakan untuk menangani kasus infertilitas.

Penelitian dilakukan untuk melihat pengaruh jintan hitam sebagai antioksidan terhadap gangguan spermatogenesis. Gangguan spermatogenesis salah satunya bersumber dari radikal bebas yang akan meningkatkan kadar malondialdehid (MDA) pada testis. Kadar MDA pada testis tikus strain Wistar digunakan sebagai indikator untuk melihat pengaruh jintan hitam dalam mencegah radikal bebas akibat paparan asap rokok subakut.

\section{METODE}

\section{Desain Penelitian}

Penelitian ini dilakukan secara eksperimental in vivo di laboratorium, untuk melihat pengaruh pemberian ekstrak jintan hitam terhadap kadar MDA dan sel spermatogonium dari testis tikus strain Wistar yang dipapar asap rokok kretek subakut. Rancangan penelitian yang digunakan adalah randomized post test only with control group design. Subjek dalam penelitian ini dibagi menjadi 5 kelompok masing-masing terdiri dari 4 ekor tikus terdiri atas 1 kelompok kontrol negatif, 1 kelompok kontrol positif yang hanya dipapar asap rokok selama 21 hari, dan 3 kelompok peralakuan yang dipapar asap rokok dan diberi ekstrak jintan hitam peroral dalam tiga dosis $(0,6 ; 1,2 ; 2,4 \mathrm{~g} / \mathrm{kgBB} /$ hari) yaitu selama 21 hari.

\section{Prosedur Pembuatan Ekstrak Jintan Hitam}

Prosedur pembutan ekstrak jintan hitam dilakukan dengan tiga prosedur, yaitu pengeringan, ekstraksi, dan evaporasi. Proses pengeringan, dengan jintan hitam dicuci sampai bersih (sampel basah), kemudian dioven dengan suhu $80^{\circ} \mathrm{C}$ atau dengan panas matahari sampai kering (bebas kandungan air). Pada proses ekstraksi, jintan hitam dihaluskan dengan blender hingga menyerupai bubuk lalu ditimbang dengan timbangan analitik sebanyak $100 \mathrm{gr}$ (sampel kering) kemudian dimasukkan ke dalam gelas ekstraksi/labu erlenmeyer ukuran $1 \mathrm{~L}$ dan direndam dalam etanol, setelah itu dikocok sampai benar-benar tercampur ( \pm 30 menit) dan kemudian diinapkan selama satu malam (12 jam) sampai mengendap. Dalam proses evaporasi, larutan yang telah diinapkan selama satu malam diambil lapisan atas dari hasil campuran etanol dengan zat aktif yang sudah terambil kemudian dimasukkan dalam labu evaporasi $1 \mathrm{~L}$ yang selanjutnya labu evaporasi dipasang pada evaporator dan diisi water bath dengan air sampai penuh. Semua rangkaian alat dipasang, termasuk rotary evaporator, pemanas water bath (diatur sampai $90^{\circ} \mathrm{C}$ ), disambungkan dengan alat listrik, selanjutnya dibiarkan sampai larutan etanol memisah dengan zat aktif yang sudah ada dalam labu ( $\pm 1,5-2$ jam untuk 1 labu). Hasil yang diperoleh kira-kira $1 / 2$ dari bahan alam kering. Ekstrak jintan hitam dimasukkan dalam botol plastik dan disimpan dalam freezer sampai digunakan, sebelum penggunaan perlu dibiarkan terlebih dahulu agar suhu sama dengan suhu ruangan.

\section{Prosedur Pemeriksaan MDA}

Kadar MDA pada jaringan testis diperiksa menggunakan metode Thio Barbituric Acid test (TBA Test). Langkahlangkah TBA test yaitu, menimbang $250 \mathrm{mg}$ jaringan testis lalu dihaluskan dan kemudian ditambahkan 2,5mL larutan buffer phosphate $\mathrm{pH} 7,4$ untuk dibuat menjadi homogenat jaringan testis. Dari homogenat jaringan testis diambil 0,5 cc dan dimasukkan pada tabung reaksi, dilakukan sebanyak dua kali. Satu tabung pada kelompok tes dan satu tabung sebagai kontrol kemudian pada tiap-tiap tabung ditambahkan larutan TCA 7,5\% sebanyak $1 \mathrm{~mL}$ dan larutan $\mathrm{HCl} 1 \mathrm{M}$ sebanyak $250 \mu \mathrm{L}$ kemudian diaduk dengan vortex. Selanjutnya menambahkan larutan TBA 0,7\% sebanyak $200 \mu \mathrm{L}$ pada kelompok tes dan tanpa larutan TBA pada kelompok kotrol dan diaduk dengan vortex. Tahap selanjutnya larutan dipanaskan pada suhu $105^{\circ} \mathrm{C}$ selama 30 menit, lalu didinginkan, kemudian larutan disentrifuge dengan kecepatan 3000 rpm selama 10 menit, diambil supernatannya dengan pipet tetes, selanjutnya pada larutan ditambahkan aquabidest sampai volumenya $3 \mathrm{cc}$, diaduk dengan vortex baru kemudian dibaca dengan spektrofotometer pada panjang gelombang $532 \mathrm{~nm}$.

\section{Metode Perhitungan Jumlah Sel Spermatogonium}

Perhitungan dilakukan dengan mengamati preparat histopatologis dari irisan testis. Langkah-langkah perhitungan yang pertama adalah pemilihan tubulus seminiferus yang baik dan bulat dengan menggunakan mikroskop dengan perbesaran 100x, kemudian difoto. Pengamatan dilanjutkan dengan mengamati preparat dengan perbesaran 200x, kemudian di foto. Pada perbesaran ini preparat di bagi 4 bagian, tiap bagian di ambil satu tubuli seminiferi yang sesuai untuk dihitung sel 
spermatogonium di dalamnya. Setelah mendapatkan tubuli seminiferi yang sesuai dilakukan perhitungan di bawah perbesaran 400x. Pada mikroskop akan tampak sel spermatogonium yang terpisah sehingga dapat dihitung. Perhitungan dilakukan dengan melihat melalui mikroskop pada preparat dan dengan mengambil foto tubulus seminiferus yang akan dihitung sel spermatogoniumnya dan dilihat pada komputer dengan menggunakan program ACDSee 10 Photo Manager. Perhitungan sel dan keliling tubulus seminiferus dilakukan meggunakan program GSA Image Analyser. Sel yang bertumpuk diambil salah satunya yang terwarna lebih gelap. Satu sediaan preparat dilakukan pengamatan 4 lapangan pandang dengan 4 kali pengulangan.

\section{HASIL}

Hasil pengamatan disajikan dalam gambar mikroskopis, serta perhitungan kuantitatif.
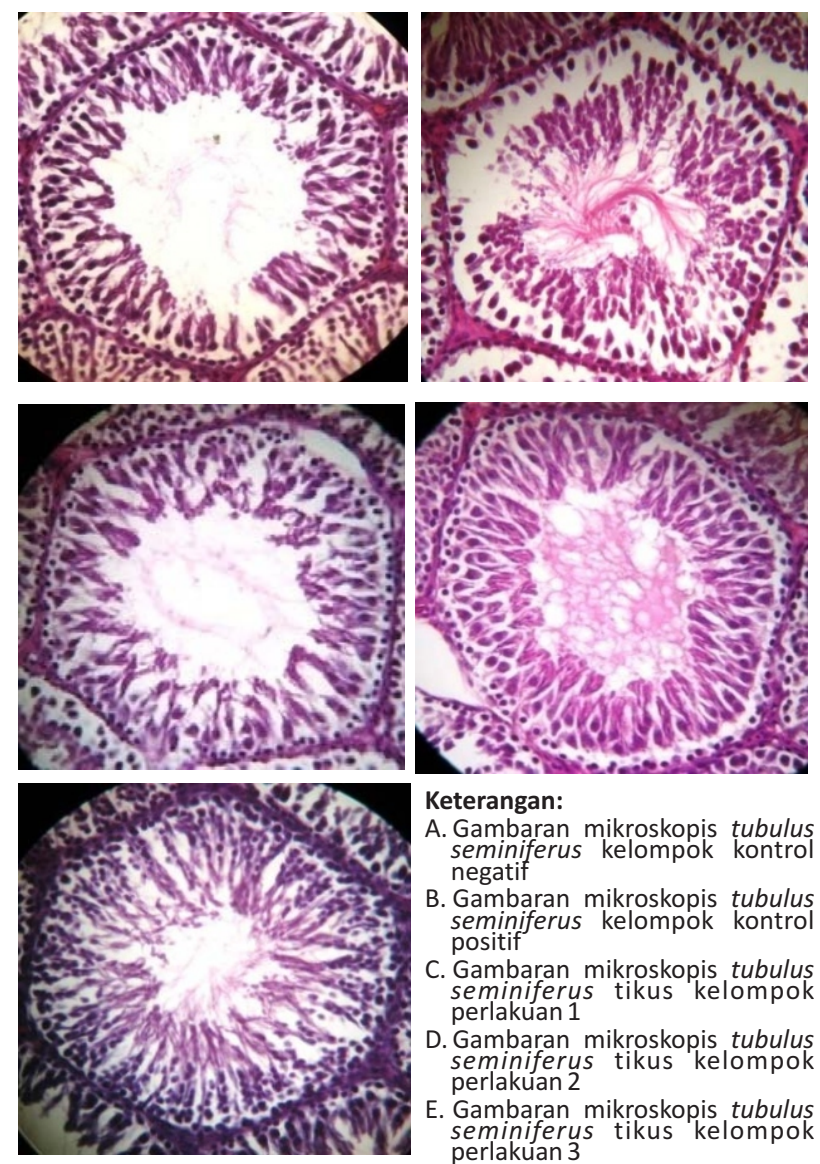

Gambar 1. Gambar mikroskopis tubulus seminiferus

Gambar (1A) menunjukkan kondisi normal tanpa paparan asap rokok. Sesudah paparan asap rokok (1B) tampak sel spermatogium rusak dan hilang, jarak antar spermatogonium lebih jauh dibandingkan kelompok kontrol negatif, jumlah sel spermatogonium jauh berkurang. Sesudah pemberian ekstrak dosis 0,6 $\mathrm{g} / \mathrm{kg} / \mathrm{BB} /$ hari (1C) tampak sel spermatogonium yang hilang lebih sedikit dibandingkan kelompok kontrol positif. Jumlah sel spermatogonium lebih banyak dibanding kelompok kontrol positif namun lebih sedikit dari kelompok kontrol negatif. Tampak sel spermatogonium yang hilang lebih sedikit dibandingkan kelompok kontrol positif dan kelompok perlakuan 1 . Jumlah sel spermatogonium lebih banyak dibanding kelompok kontrol positif dan kelompok perlakuan 1 namun masih lebih sedikit dari kelompok kontrol negatif. Sel spermatogonium mulai berjarak teratur dan melapisi seluruh lamina basalis. Sesudah pemberian ekstrak dosis 2,4 g/kgBB/hari (1E) tampak sel spermatogonium yang hilang lebih sedikit dibandingkan kelompok kontrol positif, kelompok perlakuan 1 dan 2. Jumlah sel spermatogonium lebih banyak dibanding kelompok kontrol positif, kelompok perlakuan 1 dan 2. Jumlah sel spermatogonium sebanding dengan kelompok kontrol negatif. Sel spermatogonium berjarak rapat dan melapisi seluruh lamina basis (Gambar 1).

Pada perlakuan 1 paparan asap rokok kretek dengan disertai pemberian ekstrak jintan hitam dosis 0,6 $\mathrm{g} / \mathrm{kgBB} /$ hari didapatkan rerata kadar MDA 0,0417. Nilai tersebut tidak berbeda secara bermakna dibandingkan dengan kelompok kontrol positif yang menunjukkan kadar MDA 0,049. Pada rerata jumlah sel spermatogonium kelompok perlakuan 1 (P1) yaitu 67,937 terlihat berbeda signifikan $(p<0,05)$ dengan kelompok kontrol positif (KP) yaitu 57,125, dan juga berbeda signifikan dengan kelompok kontrol negatif $(\mathrm{KN})(p<0,05)$ yang mempunyai nilai 98,625 hal itu menunjukkan masih terdapat banyak kerusakan sel spermatogonium karena jumlah selnya belum mendekati jumlah normal.

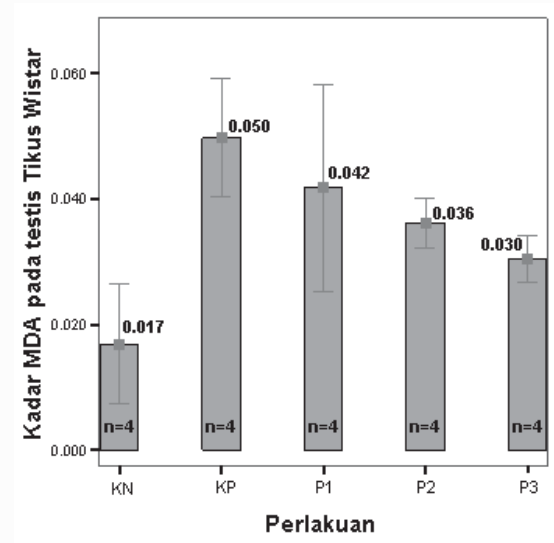

Gambar 2. Grafik kadar MDA pada testis tikus (Rattus norvegicus strain Wistar) yang dipapar asap rokok kretek subakut

Pemberian ekstrak jintan hitam dosis $1,2 \mathrm{~g} / \mathrm{kgBB} / \mathrm{hari}$ bersamaan dengan pemaparan asap rokok kretek subakut (P2) menunjukkan kadar MDA testis tikus sebesar 0,0361. Kadar MDA tersebut menunjukkan nilai yang lebih rendah secara bermakna dibandingkan tanpa jinten hitam. Kadar MDA testis yang lebih rendah secara bermakna juga ditemukan pada pemberian ekstrak jintan hitam dosis 2,4 $\mathrm{g} / \mathrm{kgBB} /$ hari (MDA 0,0304). Rerata jumlah sel spermatogonium pada kelompok perlakuan 2 (P2) dengan jumlah sel spermatogonium 87,4375 dan kelompok perlakuan 3 (P3) 1 dengan jumlah sel spermatogonium 105,0625 juga berbeda signifikan $(p<0,05)$ dengan kelompok kontrol positif (KP), bahkan hasilnya tidak berbeda signifikan $(p>0,05)$ dengan kontrol negatif $(K N)$. 


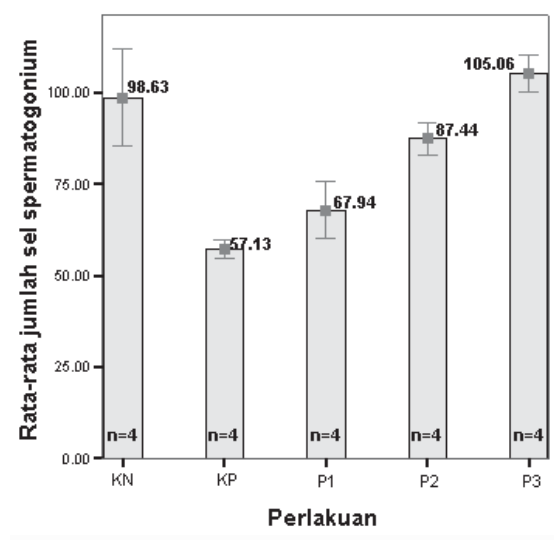

Gambar 3. Rerata jumlah sel spermatogonium pada testis Tikus (Rattus norvegicus strain Wistar) yang dipapar asap rokok kretek subakut

Keterangan:

$\mathrm{KN}=$ kontrol negatif

$\mathrm{KP}=$ kontrol positif

$\mathrm{P} 1=0,6 \mathrm{~g} / \mathrm{kg} / \mathrm{BB} /$ hari

$\mathrm{P} 2=1,2 \mathrm{~g} / \mathrm{kg} / \mathrm{BB} /$ hari

$\mathrm{P} 3=2,4 \mathrm{~g} / \mathrm{kg} / \mathrm{BB} / \mathrm{hari}$

Berdasarkan hasil analisis statistik ANOVA terdapat perbedaan efek pemberian jintan hitam yang bermakna (signifikan) antara setiap perlakuan terhadap kadar MDA dan rerata jumlah sel spermatogonium pada testis tikus strain Wistar yang dipapar asap rokok kretek subakut, ditunjukkan dengan korelasi negatif antara rerata jumlah sel spermatogonium dan kadar MDA testis. Korelasi negatif ini telah dibuktikan dengan uji statistik dan disimpulkan bahwa antara kadar MDA pada testis tikus strain Wistar yang dipapar asap rokok kretek subakut dengan sel spermatogonium $(r=-0,747, p=0,000)$.

\section{DISKUSI}

Hasil penelitian ini menunjukkan bahwa pemaparan asap rokok kretek subakut pada tikus strain Wistar dapat meningkatkan kadar MDA testis secara bermakna dibandingkan normal. Hal ini dikarenakan efek dari asap rokok yang mengandung radikal bebas yang kuat dan dapat menyebabkan stres oksidasi pada sel-sel spermatogenik di tubulus seminiferus testis. Stres oksidasi pada testis dapat menyebabkan gangguan pada proses oksidasi fosforilasi sehingga terjadi peningkatan produksi radikal bebas. Peningkatan radikal bebas ini disebabkan karena antioksidan yang tersedia dalam tubuh tidak mampu lagi mengubah oksigen reaktif $\left(0^{*}\right)$ menjadi senyawa yang netral $\left(\mathrm{O}_{2}\right)$. Antioksidan tersebut memberikan pertahanan yang sangat efektif terhadap peroksidasi lipid, tetapi stres oksidasi yang berat dapat berakibat pada habisnya antioksidan yang tersedia (6).

Adanya peroksidasi lipid pada membran sel spermatogenik menghasilkan senyawa MDA. Dengan demikian kadar MDA yang tinggi menunjukkan terjadinya peroksidasi lipid pada membran sel spermatogenik. Keadaan ini diindikasikan dengan menurunnya jumlah sel spermatogonium pada kelompok kontrol positif secara signifikan dibandingkan dengan kelompok kontrol negatif. Pemeriksaan histopatologis menunjukkan penurunan rerata sel spermatogonium pada kelompok kontrol positif.
Ini disebabkan banyaknya sel spermatogonium yang rusak dan terjadi kematian sel akibat peroksidasi lipid pada membran sel spermatogonium. Peroksidasi lipid merupakan proses pembentukan peroksida dari asam lemak yang memiliki ikatan rangkap yang diselingi gugus metilen $\left(-\mathrm{CH}_{2}-\right)$, yaitu ikatan dalam PUFA. Hasil akhir peroksidasi lipid pada membran adalah terputusnya rantai asam lemak tidak jenuh dan menghasilkan MDA spermatogonium dan menyebabkan apoptosis sel spermatogonium, sehingga jumlah sel spermatogonium pada tubulus seminiferus kelompok kontrol positif jauh berkurang daripada kelompok kontrol negatif (7).

Peningkatan kadar MDA pada testis tikus strain Wistar yang dipapar asap rokok kretek subakut, mempunyai korelasi dengan penurunan jumlah sel spermatogonium pada testis tikus strain Wistar. Faktor-faktor lain selain kadar MDA juga mempengaruhi kerusakan sel spermatogonium seperti infeksi yang menyebabkan peningkatan leukosit yang dapat merusak sel spermatogenik. Suhu juga sangat berpengaruh dalam menjaga integritas membran sel spermatogenik. Sel spermatogenik yang sangat sensitif harus terjaga pada suhu tertentu, jika suhu terlalu tinggi dapat merusak sel spermatogenik, seperti yang terjadi pada varicocele.

Dosis antioksidan yang terkandung dalam ekstrak jintan hitam dosis 0,6 g/kgBB/hari belum mampu mengimbangi aktivitas radikal bebas berlebih di dalam tubuh akibat paparan asap rokok kretek subakut. Hal ini diduga terjadi akibat aktivitas antioksidan yang terkandung dalam ekstrak jintan hitam seperti thymoquinone, nigellone, carvacrol, t-anethole dan 4-terpineol. Hasil penelitian ini didukung oleh penelitian sebelumnya bahwa Nigella sativa dapat mencegah kerusakan sel dan jaringan pada testis tikus (8).

Salah satu fungsi thymoquinone adalah sebagai antioksidan dengan cara menghambat reaksi propagasi radikal bebas. Thymoquinone dapat menghambat peroksidasi lipid melalui perannya sebagai scavenger terhadap radikal superoksida $\left(\mathrm{O}_{2}^{-}\right)$dan membentuk senyawa lain yang tidak reaktif (9). Kemampuan sebagai scavenger tersebut juga efektif terhadap radikal hidroksil $(\mathrm{OH})(5)$. Thymoquinone juga dapat meningkatkan GSH sehingga efek proteksi terhadap radikal bebas bisa meningkat. GSH yang berikatan dengan peroksida hidrogen akan direduksi oleh GSH peroksidase menjadi air dan alcohol (10). Nigellone yang merupakan polimer karbonil dari thymoquinone juga diketahui mempunyai sifat farmakologis seperti thymoquinone sebagai antioksidan (3). Antioksidan carvacrol, t-anethole dan 4terpineol belum diketahui dengan pasti mekanisme kerjanya, tetapi penelitian yang dilakukan oleh Burits et al. (2000) menunjukkan bahwa baik thymoquinone, carvacrol, t-anethole maupun 4-terpineol menunjukkan kemampuan sebagai scavenger radikal bebas dengan baik. Mekanisme antioksidan yang bervariasi dari keempat bahan aktif yang ada pada jintan hitam membuat jintan hitam lebih unggul dari antioksidan kimiawi. Antioksidan kimiawi bagai pedang bermata dua. Pertama, saat bahan tereduksi menjadi radikal maka derivat radikalnya juga terbentuk. Sehingga, jika suatu radikal sangat tidak stabil, reaksi radikal berantai mungkin akan berlanjut. Kedua, bahan tereduksi dapat mereduksi oksigen menjadi superoksida atau peroksida merupakan radikal hidroksil dalam reaksi auto-oksidasi. Sedangkan pada jintan hitam 
hasil sampingan berupa radikal yang tidak stabil segera dihambat dengan kemampuannya sebagai scavanger dan donor elektron sehingga menghasilkan senyawa yang lebih stabil, sehingga reaksi radikal berantai dapat dicegah (5).

Hasil penelitian menunjukkan bahwa pemberian jintan hitam dengan kadar MDA pada testis tikus strain Wistar yang dipapar asap rokok kretek subakut $(r=-0,772$, $p=0.000)$ mempunyai hubungan yang signifikan $(p<0.05)$ dengan arah korelasi yang negatif. Artinya peningkatan perlakuan berupa jintan hitam cenderung akan menurunkan kadar MDA pada testis tikus strain Wistar yang dipapar asap rokok kretek subakut, dibandingkan dengan kadar MDA pada testis tikus pada kelompok kontrol. Ini dapat disimpulkan bahwa jintan hitam dapat menghambat pembentukan MDA.

Pemberian jintan hitam dengan rerata jumlah sel spermatogonium pada testis tikus strain Wistar yang dipapar asap rokok kretek subakut $(r=0,975, p=0,000)$ mempunyai hubungan (korelasi) yang signifikan $(p<0,05)$ dengan arah korelasi yang positif. Peningkatan perlakuan berupa jintan hitam cenderung akan meningkatkan rerata jumlah sel spermatogonium pada testis tikus strain Wistar yang dipapar asap rokok kretek subakut, dibandingkan dengan rerata jumlah sel spermatogonium pada testis tikus pada kelompok kontrol.

Hasil penelitian ini menjawab hipotesis peneliti, bahwa jintan hitam yang mengandung antioksidan terbukti dapat mencegah penurunan rerata jumlah sel spermatogonium pada tubulus seminiferus testis tikus strain Wistar yang

\section{DAFTAR PUSTAKA}

1. Rapurkar A, Jiang Y, Dhabuwala CB, Dunbar JC, and Li H. 2002. Cigarette Smoking Induces Apoptosis in Rat Testis. Journal of Environmental Pathology, Toxology, and Oncology. 2002; 21(3): 243-248.

2. Anita N. Perubahan Sebaran Stadia Epitel Seminiferus, Penurunan Jumlah Sel-sel Spermatogenik, dan Kadar Hormon Testosteron Total Mencit (Mus musculus L.) Galur DDY yang Diberi Asap Rokok Kretek. [Tesis]. Universitas Indonesia, Jakarta. 2004.

3. Avisiena. Primary Properties of Black Seed. (Online) 2000. http://www.blackseedusa.com [diakses tanggal 10 November 2007].

4. Bawadi $\mathrm{H}$. Insight into Underutilized Bioactive Active Compounds of Black Seed. IFT Annual Meeting. New Orleans, Lousiana, July 15-20 2005.

5. Burits M and Bucar F. Antioxidant Activity of Nigella sativa Essential Oil. Phytotherapy Research. 2000; 14(5): 323-328. dipapar asap rokok kretek subakut melalui hambatannya pada pembentukan peroksidasi lipid (MDA). Hasil penelitian ini diperoleh hanya sampai dosis yang diteliti yaitu 2,4 g/kgBB/hari. Belum diketahui apakah kandungan antioksidan dalam jintan hitam pada dosis yang berlebihan dapat berubah menjadi prooksidan sehingga dapat memperparah kerusakan oksidatif akibat radikal bebas. Dalam penelitian ini juga tidak diketahui dosis toksik jintan hitam pada tikus strain Wistar sehingga perlu dilakukan uji toksisitas ekstrak jinten hitam.

Berdasarkan hasil dan pembahasan dalam penelitian ini dapat ditarik kesimpulan bahwa pemberian jintan hitam terbukti dapat meningkatkan penurunan rerata jumlah sel spermatogonium pada testis tikus (Rattus norvegicus) strain Wistar yang dipapar asap rokok kretek subakut melalui penghambatan pembentukan peroksidasi lipid yang dilihat dari penurunan kadar MDA. Peningkatan kadar MDA pada testis tikus yang dipapar asap rokok kretek subakut, diikuti penurunan jumlah sel spermatogonium pada testis tikus strain Wistar. Dengan pemberian jintan hitam (Nigella sativa) terjadi penurunan kadar MDA testis diikuti peningkatan jumlah sel spermatogonium tubulus seminiferus testis tikus pada tikus (Rattus novergicus) strain Wistar yang dipapar asap rokok kretek subakut. Dosis optimal ekstrak jinten hitam (Nigella sativa) yang dapat mencegah penurunan rerata sel spermatogonium testis tikus (Rattus novergicus) strain Wistar yang dipapar asap rokok kretek subakut adalah 2,4 $\mathrm{g} / \mathrm{kgBB} /$ hari.

6. Jeffery EH. Bioshemical Mechanisme of Toxic Cell Injury. In: Haschek W and Rousseaux CG (Eds). Handbook of Toxicologic Pathology. Urbana: Academic Press Inc; 1991; p. 49-87.

7. Sanocka D and Kurpisz M. Reactive Oxygen Species and Sperm Cells. Reproductive Biology and Endocrinology. 2004; 2(12): 1-7.

8. Ali $\mathrm{AB}$ and Ali TH. Effect of Ultraviole-Ray on the Spermatogenesis and Testes Tissues of Albino Swiss Mice. Research \& Review in BioSciences. 2007; 1(3).

9. Badary OA, Taha RA, Gamal el-Din AM, and AbdelWahad MH. Thymoquinone is a Potent Superoxide Anion Scavenger. Drug and Chemical Toxicology. 2003; 26(2): 87-98.

10. El-Dakhakhny M, Madi NJ, Lembert N, and Ammon N. Nigella Sativa Oil, Nigellone and Derived Thymoquinone Inhibit Synthesis of 5-Lipoxygenase Products in Polymorphonuclear Leukocytes from Rats. Journal Ethmopharmacology. 2002; 81(2): 161-164. 